\title{
The Role of Internal Control Components on Financing Activities in Jordan Islamic Bank (North Region)
}

\author{
Hani Ali Aref Al-Rawashdeh ${ }^{1}$ \\ ${ }^{1}$ Accounting Department, Faculty of administrative and financial sciences, Irbid National University, Jordan \\ Correspondence: Hani Ali Aref Al-Rawashdeh, Assistant Professor Dr., Accounting Department, Faculty of \\ Administrative and Financial Sciences, Irbid National University P.O Box: 2600-Zip Code: 21110, Jordan. \\ E-mail: hrawashdeh73@yahoo.com
}

Received: November 2, 2017

Accepted: December 26, 2017

Online Published: January 5, 2018

doi:10.5539/ijef.v10n2p57

URL: https://doi.org/10.5539/ijef.v10n2p57

\begin{abstract}
The current study aims to define the role of internal control components on financing activities in Jordan Islamic Bank. The study population was made of all the funding granting committees' employees in Jordan Islamic Bank (North region); (48) employees in (2017). The study sample included the study population as a whole, but due to the absence of some employees, the study sample was made of (40) employees as a result. To accomplish the study objectives, both; the descriptive and analytical approaches have been used, besides (T-test) and simple linear regression analysis. The study reached several results, the most important among them were: there is a statistically significant role for the internal control components on the financing activities in Jordan Islamic Bank (North region) at Sig. $(\alpha \leq 0.05)$, with a high level. there is a statistically significant role for the internal control environment over the financing activities in Jordan Islamic Bank (North region) with a very high level at Sig. $(\alpha \leq 0.05)$, there is a statistically significant role for the internal control activities accredited by the internal control committees over the financing activities in Jordan Islamic Bank (North region) with a very high level at Sig. $(\alpha \leq 0.05)$, there is a statistically significant role for the communication and information system applied by the internal control committees over the financing activities in Jordan Islamic Bank (North region) with a very high level at Sig. $(\alpha \leq 0.05)$, there is a statistically significant role for the follow-up system adopted by the internal control committees over the financing activities in Jordan Islamic Bank (North region) with a very high level at Sig. $(\alpha \leq 0.05)$, and there is a statistically significant role for the risk assessment system applied by the internal control committees over the financing activities in Jordan Islamic Bank (North region) with a medium level at Sig. $(\alpha \leq 0.05)$. Based on these results, the researcher recommended the importance of developing the internal control environment and increasing its efficiency, besides, maintaining the quality of policies and procedures that helps guaranteeing executing the management views and developing the risk assessment system.
\end{abstract}

Keywords: internal control environment, internal control activities, information and communication, risks assessment, follow-up, financing activities, Jordan Islamic Bank

\section{Introduction}

Internal control (in any bank) aims to guarantee achieving the bank objectives in its operational efficiency, productive efficiency and preparing reliable financial reports. Internal control includes all what control the risks that the bank might go through.

On the organizational level, internal control aims to guarantee the credibility of financial reports and timely responses to the achievement of operational objectives.

The financing activities in the Islamic Bank represent the financing formulas that the Islamic Bank use, which in their place represent the core of the Islamic bank business through which the bank aims to achieve real development in the national economy.

Out of this, we came up with the study's idea to identify the role of internal control components on financing activities in Jordan Islamic Bank (North region) to guarantee accomplishing the Islamic Bank objectives represented in achieve real development in the national economy.

\subsection{Study Problem}

The main goal of internal control in Jordan Islamic Bank is guaranteeing accomplishing the bank objectives 
represented in increasing the operational efficiency, the productive efficiency and achieving real development in the national economy. Based on this, the study problem emerged to identify the role of internal control in achieving the bank objectives through the financing activities and through answering the following questions:

Q0: Is there a role for the internal control components over the financing activities in Jordan Islamic Bank (North region)? From this question we have the following sub-questions:

Q01: Is there a role for the internal control environment over the financing activities in Jordan Islamic Bank (North region).

Q02: Is there a role for the follow-up system over the financing activities in Jordan Islamic Bank (North region).

Q03: Is there a role for the communication and information system over the financing activities in Jordan Islamic Bank (North region).

Q04: Is there a role for the internal control activities over the financing activities in Jordan Islamic Bank (North region).

Q05: Is there a role for the risk assessment system over the financing activities in Jordan Islamic Bank (North region).

\subsection{Study Objectives}

1) Identifying the concept of internal control and its components.

2) Highlighting the concept of Jordan Islamic banks.

3) Identifying the types of financing activities in Jordan Islamic bank.

4) Identifying the role of internal control components on the financing activities in Jordan Islamic Bank (North region).

\subsection{Study Importance}

The importance of this study emerges from the importance of Islamic banks' sector and their role in the real development of national economy through the Islamic bank's financing activities; moreover, the importance of internal control in maintaining the funds deposited in Islamic banks and guaranteeing the accuracy in the methods, means and procedures applied in granting Islamic funds.

\subsection{Study Hypotheses}

H0: There is no role for the internal control components over the financing activities in Jordan Islamic Bank (North region). This has the following sub-hypotheses:

H01: There is no role for the internal control environment over the financing activities in Jordan Islamic Bank (North region).

H02: There is no role for the follow-up system over the financing activities in Jordan Islamic Bank (North region).

H03: There is no role for the internal communication and information system over the financing activities in Jordan Islamic Bank (North region).

H04: There is no role for the internal control activities over the financing activities in Jordan Islamic Bank (North region).

H05: There is no role for the risk assessment system over the financing activities in Jordan Islamic Bank (North region).

\subsection{What Distinguishes This Study from Previous Studies}

This study considered internal control components as an independent variable and it studied its role over the financing activities as a dependent variable in Jordan Islamic Bank (North region). 


\subsection{Study Model}

\begin{tabular}{|c|c|}
\hline Independent variable: internal control components & Dependent variable \\
\hline \multicolumn{2}{|l|}{ 1. Internal control environment } \\
\hline 2. Internal control activities & Financing activities in Jordan Islamic Bank (North region) \\
\hline \multicolumn{2}{|l|}{ 3. Communication and information } \\
\hline \multicolumn{2}{|l|}{ 4. Follow-up system } \\
\hline 5. Risk assessment & \\
\hline
\end{tabular}

Source: By the researcher (2017).

\section{Theoretical Framework}

\subsection{Internal Control}

Internal Control is the organizational plan, methods and procedures developed by the organization to assist in achieving management objectives, ensuring the integrity and efficiency of the implementation of the organization's work and the application of management policies, the preservation of assets and properties from fraud and loss, preventing and detecting errors, if any, Ensuring the correctness and completeness of the accounting records and preparing sound financial data in a timely manner (Ghunaimat \& Siyam, 2011, p. 629).

The Committee of Sponsoring Organizations (COSO) defined it as all the means and procedures used by the entity to protect its assets and to ensure the accuracy and completness of accounting and statistical data to raise the productive efficiency in the company and achieve effectiveness (Al-Wardat, 2014, p. 313).

Also a system of internal control consists of policies and procedures designed to provide management with reasonable assurance that the company achieves its objectives and goals (Arens, 2014).

\section{Internal control components are divided into:}

\section{1). The control environment}

The control environment is the policies and procedures that reflect the views of senior management and board of directors about control and its importance to the company, and it constitutes the basis of the rest of control components (Amin, 2012)

\section{2). The control activities}

The control activities are the policies and procedures that help to ensure the implementation of management directives and take action to address risks and meet the objectives previously set by the entity. (Edward, 2011)

\section{3). Risk assessment}

Risk assessment is identifying the risks facing the entity, analyze them, the reasons for their occurrence, and assess the degree of their seriousness and the extent of their impact on the financial data. (Saidin, 2013)

4). Communication and information is defined as the process of identifying and communicating suitable information appropriately to all parties in the entity and within a time frame in order to achieve the objectives of financial reports (Saidin, 2013).

\section{5). Follow-up (monitoring and control)}

It is the periodic and continuous assessment of the various internal control components by the administration in order to determine whether they are working in the required way, and determine the need for the necessary development and identify weaknesses in the applied control system (Al-Madhoun, 2014).

\subsection{Islamic Banks Definition}

Islamic banks are the entities that run their banking operations based on the Islamic legislation and doctrine. The Islamic Bank is a banking financial institution that collects funds and employs them within the scope of Islamic legislation, which serves building a society with Islamic solidarity, achieving justice in distribution and operating money in an Islamic way (Rawashdeh \& Al-Bawab, 2016).

Financing activities in Islamic banks are defined as: providing the necessary funding, in whole or in part, through self-liquidating operations, including Mudarabah, decreasing Musharakah, Murabaha of purchase request and other similar operations (Hammadi, 2015).

The financing formulas of Jordan Islamic Bank are as follows: 
1). Financing through Murabaha; 2). Financing through Ijara; 3). Istisna; 4). Musharakah; 5). Financing services; 6). Good loans (no interest); 7). Bargaining sale (Jordan Islamic Bank).

\section{We will identify and clarify some financing formulas used in Jordan Islamic Bank:}

\section{1). Murabaha}

"According to jurists, it is the sale with the same capital of sale with the increase of a known profit: that the seller tells the buyer of the price at which he bought the commodity "(Standard No. 2 of Accounting and Auditing of Islamic Financial Institutions, p. 154).”

\section{2). Murabaha of purchase request}

"It Is the negotiated sale by two or more parties who agree on the implementation of this negotiation, where the requesting part requires the requested party to buy a commodity and promises to buy the commodity back from the requested party against agreed profit" (Standard No. 2 of Accounting and Auditing of Islamic financial institutions, p. 155).

\section{3). Mudaraba}

Is a sharing in profit between money and work and is held between the owners of investment accounts (capitalists) and the bank (Mudarib), which declares a general acceptance of those funds to invest them and to distribute the profit as agreed" (Standard No. 3 of Accounting and Auditing of Islamic Financial Institutions, p. 193).

\section{4). Musharakah}

"Is that the bank and the customer provide equal or varying amounts of money in order to establish a new project or to contribute in an existing project, so that each of them owns a share in the capital in a fixed or decreasing manner and is entitled to its share of the profits, moreover; loss is divided according to the share of each partner in the capital and it is not valid to require otherwise, "(Standard No. 4 of Accounting and Auditing of Islamic Financial Institutions, p. 221).

\section{5). Istisna}

"A contract of sale between the customer (the buyer) and the manufacturer (the seller), so that the second - at the request of the first manufacture a described commodity or obtained at the time of delivery provided that the manufactured material or the cost of work is from the manufacturer for a price agreed upon and both agree how to pay it" (Accounting, Auditing and Controls for Islamic Financial Institutions, Standard No. 10 for Accounting and Auditing of Islamic Financial Institutions, p. 372).

\section{6). Ijara}

"It is leasing that ends with ownership of leased assets" (Standard No. 8 of Accounting and Auditing of Islamic Financial Institutions, p. 323).

\section{Analysis and Testing Hypotheses}

\subsection{Study Methodology}

The researcher used the descriptive and analytical approaches in collecting and analyzing data. He designed a questionnaire and distributed it over the study sample to collect data and then to analyze it. He also tested the hypotheses to reach the results of the study. It should be noted that the researcher relied on a previous study of his own (Al-rawashdah, 2017) entitled "The role of internal control components in the maintenance of public money" and he used the same independent variables used in that study.

\subsection{Study Population and Sample}

The study population is made of all the funding granting committees' employees in Jordan Islamic Bank (North region); (48) employees (males and females).

Study sample: (48) questionnaires have been distributed among the funding granting committees' employees in Jordan Islamic Bank (North region). (42) Questionnaires were retrieved and (2) questionnaires were excluded for being inappropriate for the analysis purposes. The final study sample was made of (40) employees (males and females). The following table shows the distribution of the sample according to the study variables: (sex, age, work service period). 
Table 1. Descriptive data of the study sample members

\begin{tabular}{llll}
\hline According to & & Number & Percentage \\
\hline Sex & Male & 25 & $62.5 \%$ \\
& Female & 15 & $37.5 \%$ \\
Age & 25 years or less & 8 & $20 \%$ \\
& From 26 to 36 years & 22 & $55 \%$ \\
\multirow{2}{*}{ work service period } & From 37 to 47 years & 10 & $25 \%$ \\
& Less than 5 years & 19 & $47.5 \%$ \\
& From 5 to 9 years & 8 & $20 \%$ \\
\hline Total & From 10 to 15 years & 13 & $32.5 \%$ \\
\hline
\end{tabular}

Source: By the researcher (2017).

From the distribution of the study sample members we conclude that the sample has the complete knowledge and experience to answer the study tool items, this in return will provide real and highly accurate information to answer the study hypotheses and conclude the results accordingly.

\subsection{Data Collecting Sources}

1). Books, studies and researches related to the subject of the study have been relied on.

2). The study tool was used to obtain data related to the study population.

\subsection{Study Tool}

The researcher designed a questionnaire made of (32) items based on Likert Quintet method, as follows:

1. (5) items about the role of internal control environment over the financing activities in Jordan Islamic Bank.

2. (10) items about the role of the follow-up system over the financing activities in Jordan Islamic Bank.

3. (7) items about the role of communication and information system over the financing activities in Jordan Islamic Bank.

4. (4) items about the role of internal control activities over the financing activities in Jordan Islamic Bank.

5. (6) items about the role of risk assessment over the financing activities in Jordan Islamic Bank.

The evaluative verbal expressions used in the study tool

\begin{tabular}{|ccccc|}
\hline Highly agree & Agree & Neutral & Don't agree & Highly don't agree \\
\hline 5 & 4 & 3 & 2 & 1 \\
\hline
\end{tabular}

\subsubsection{Study Tool Reliability}

The researcher used Cronbach's alpha coefficient to calculate the reliability coefficient of the study tool. The reliability result was (88.4).

\subsubsection{Statistical Processing}

The researcher used the statistical analysis software (SPSS), he also applied (One sample T-test) and the simple linear regression analysis.

\subsubsection{The Comparative Standard for the Study Tool Items}

In order for the researcher to determine the level of the role of the internal control components over the financing activities in Jordan Islamic Bank (Northern Region), he derived the following standard, based on the verbal evaluation of the study tool and the number of items of each axis as follows:

\begin{tabular}{cc}
\hline The comparative standard of the main hypothesis (internal control components) \\
\hline $32-57.5$ & Very low \\
$57.6-83.1$ & Low \\
$83.2-108-7$ & Medium \\
$108.8-134.3$ & High \\
$134.4-160$ & Very high \\
\hline
\end{tabular}




\begin{tabular}{cccccc}
\hline \multicolumn{7}{c}{ The comparative standard for the sub-hypotheses } \\
\hline & Very low & Low & Medium & High & Very high \\
\hline Internal control environment & $5-8.9$ & $9-12.9$ & $13-16.9$ & $17-20.9$ & $21-25$ \\
Follow-up system & $10-17.9$ & $18-25.9$ & $26-33.9$ & $34-41.9$ & $42-50$ \\
Information and communication system & $7-12.5$ & $12.6-18.1$ & $18.2-23.7$ & $23.8-29.3$ & $29.4-35$ \\
Internal control activities & $4-7.1$ & $7.4-10.3$ & $10.4-13.5$ & $13.6-16.7$ & $16.8-20$ \\
Risk assessment & $6-10.7$ & $10.8-15.5$ & $15.6-20.3$ & $20.4-25.1$ & $25.2-30$ \\
\hline
\end{tabular}

After comparing the arithmetic average in T-test with the comparative standard of the study tool items, their role was found as follows:

\begin{tabular}{lcc}
\hline \multicolumn{1}{c}{ Item } & Arithmetic average & The role level \\
\hline Internal control components & $\rightarrow 129.67 \rightarrow$ & Very high \\
Internal control environment & $\rightarrow 21.88 \rightarrow$ & Very high \\
Follow-up system & $\rightarrow 43.22 \rightarrow$ & Very high \\
Information and communication system & $\rightarrow 29.79 \rightarrow$ & Very high \\
Internal control activities & $\rightarrow 17.98 \rightarrow$ & Very high \\
Risk assessment & $\rightarrow 16.79 \rightarrow$ & Medium \\
\hline
\end{tabular}

\subsection{Study Hypotheses Testing Results}

H0: There is no role for the internal control components over the financing activities in Jordan Islamic bank (North region).

Table 2. T-test results

\begin{tabular}{cccccc}
\hline Number & Arithmetic average & Standard deviation & T & DF & Sig (2-tailed) \\
\hline 40 & 129.67 & 9.24 & 102.15 & 39 & 0.000 \\
\hline
\end{tabular}

From the previous table we see that the calculated $(\mathrm{T})$ value (102.15) is bigger than the $(\mathrm{T})$ table value (2.021). Based on this, we reject the non-hypothesis and we accept its alternative which confirms that there is a role of statistical significance at sig. $(\alpha \leq 0.05)$ for the internal control components over the financing activities in Jordan Islamic Bank (North region), and after comparing the arithmetic average to the comparative standard we found that this role is high.

H01: There is no role for the internal control environment over the financing activities in Jordan Islamic Bank (North region).

Table 3. T-test results

\begin{tabular}{cccccc}
\hline Number & Arithmetic average & Standard deviation & T & DF & Sig (2-tailed) \\
\hline 40 & 21.88 & 1.75 & 91.03 & 39 & 0.000 \\
\hline
\end{tabular}

The previous table shows that the calculated (T) value (91.03) is bigger than the (T) table value (2.021). Based on this, we reject the non-hypothesis and we accept its alternative which confirms that there is a role of statistical significance at sig. $(\alpha \leq 0.05)$ for the internal control environment over the financing activities in Jordan Islamic Bank (North region) and after comparing the arithmetic average to the comparative standard we found that this role is very high.

The researcher used the simple linear regression analysis to measure this role over the financing activities in Jordan Islamic Bank (North region).

Table 4. The analysis results

\begin{tabular}{cccccccc}
\hline Independent variable & $\mathrm{R}$ & $\mathrm{R}^{2}$ & $\mathrm{~F}$ & $\mathrm{Sig} \mathrm{f}$ & $\mathrm{DF}$ & $\mathrm{T}$ & $\mathrm{Sig} \mathrm{t}$ \\
\hline Internal control environment & & & & & & & \\
& 0.480 & 0.231 & 15.297 & 0.000 & 38 & 5.21 & 0.000 \\
\hline
\end{tabular}


We notice that the internal control environment has a role in the financing activities in Jordan Islamic Bank (North region), the value of $\mathrm{R}$ is $(0.480)$, and it indicates a medium level of correlation. The $\mathrm{R}^{2}$ value for the internal control environment role over the financing activities in Jordan Islamic Bank (North region) was (0.231), this relation is statistically acceptable because the calculated (f) value (15.297) is bigger than the (F) table value (4.00), and it has significance at $\operatorname{Sig}(\alpha \leq 0.05)$.

The $(\mathrm{T})$ test value shows the linear importance of the independent variable in the regression, the (T) Sig. value was $(0.000)$ which is less than the Alpha value $(0.05)$, this means that there is a linear importance for the internal control environment over the financing activities in Jordan Islamic Bank (North region). By this result, we reject the first non-hypothesis.

H02: There is no role for the follow-up system over the financing activities in Jordan Islamic Bank (North region).

Table 5. T-test results

\begin{tabular}{cccccc}
\hline Number & Arithmetic average & Standard deviation & T & DF & Sig (2-tailed) \\
\hline 40 & 43.22 & 4.17 & 75.42 & 39 & 0.000 \\
\hline
\end{tabular}

From the table we see that the (T) calculated value (75.42) is bigger than the (T) table value (2.021), Based on this we reject the non-hypothesis and we accept the alternative hypothesis which confirms that there is a role for the follow-up system at sig. $(\alpha \leq 0.05)$ over the financing activities in Jordan Islamic Bank (North region) and by comparing the arithmetic average to the comparative standard we found that this role is very high.

The researcher used the simple linear regression analysis to measure this role over the financing activities in Jordan Islamic bank (North region).

Table 6. The analysis results

\begin{tabular}{cccccccc}
\hline Independent variable & $\mathrm{R}$ & $\mathrm{R}^{2}$ & $\mathrm{~F}$ & $\mathrm{Sig} \mathrm{f}$ & $\mathrm{DF}$ & $\mathrm{T}$ & $\mathrm{Sig} \mathrm{t}$ \\
\hline The follow-up system & & & & & 1 & & \\
& 0.756 & 0.571 & 68.01 & 0.000 & 38 & 6.49 & 0.000 \\
\hline
\end{tabular}

From the previous table we see that the follow-up system affects the financing activities in Jordan Islamic Bank (North region), the value of $\mathrm{R}$ is $(0.756)$, and it indicates a high level of correlation. The $\mathrm{R}^{2}$ value for the role of the follow-up system over the financing activities in Jordan Islamic Bank (North region) was (0.571), this relation is statistically acceptable because the calculated (f) value (68.01) is bigger than the (F) table value (4.00), and it has significance at $\operatorname{Sig}(\alpha \leq 0.05)$.

The (T) test value shows the linear importance of the independent variable in the regression, the (T) Sig. was (0.000) which is less than the Alpha value (0.05), this means that there is a linear importance for the follow-up system over the financing activities in Jordan Islamic Bank (North region). By this result, we reject the second non-hypothesis.

H03: There is no role for the communication and information system over the financing activities in Jordan Islamic Bank (North region).

Table 7. T-test results

\begin{tabular}{cccccc}
\hline Number & Arithmetic average & Standard deviation & T & DF & Sig (2-tailed) \\
\hline 40 & 29.79 & 3.12 & 69.34 & 39 & 0.000 \\
\hline
\end{tabular}

From the table we see that the (T) calculated value (69.34) is bigger than the (T) table value (2.021), Based on this we reject the non-hypothesis and we accept the alternative hypothesis which confirms that there is a statistically significant role at sig. $(\alpha \leq 0.05)$ for the communication and information system over the financing activities in Jordan Islamic Bank (North region) and by comparing the arithmetic average to the comparative standard we found that this role is very high.

The researcher used the simple linear regression analysis to measure this role over the financing activities in Jordan Islamic bank (North region). 
Table 8. The analysis results

\begin{tabular}{cccccccc}
\hline Independent variable & $\mathrm{R}$ & $\mathrm{R}^{2}$ & $\mathrm{~F}$ & $\mathrm{Sig} f$ & $\mathrm{DF}$ & $\mathrm{T}$ & Sig t \\
\hline Communication and information system & & & & & 1 & & \\
& 0.430 & 0.185 & 11.574 & 0.000 & 38 & 8.207 & 0.000 \\
\hline
\end{tabular}

From the previous table we see that the communication and information system affects the financing activities in Jordan Islamic Bank (North region), the value of $\mathrm{R}$ is (0.430), and it indicates a medium level of correlation. The $\mathrm{R}^{2}$ value for the effect of communication and information system over the financing activities in Jordan Islamic Bank (North region) was (0.185), this relation is statistically acceptable because the calculated (f) value (11.574) is bigger than the (F) table value (4.00), and it has significance at $\operatorname{Sig}(\alpha \leq 0.05)$.

The $(\mathrm{T})$ test value shows the linear importance of the independent variable in the regression, the $(\mathrm{T})$ Sig. was $(0.000)$ which is less than the Alpha value (0.05), this means that there is a linear importance for the communication and information system over the financing activities in Jordan Islamic Bank (North region).

By this result, we reject the third non-hypothesis.

H04: There is no role for the internal control activities over the financing activities in Jordan Islamic Bank (North region).

Table 9. T-test results

\begin{tabular}{cccccc}
\hline Number & Arithmetic average & Standard deviation & T & DF & Sig (2-tailed) \\
\hline 40 & 17.98 & 2.06 & 63.50 & 39 & 0.000 \\
\hline
\end{tabular}

From the table we see that the calculated (T) value (63.50) is bigger than the (T) table value (2.021) and for this we reject the non-hypothesis and we accept the alternative hypothesis which confirms that there is a role of statistical significance at sig. $(\alpha \leq 0.05)$ for the internal control activities over the financing activities in Jordan Islamic bank (North region) and by comparing the arithmetic average to the comparative standard we found that this role is very high.

The researcher used the simple linear regression analysis to measure this role over the financing activities in Jordan Islamic bank (North region).

Table 10. The analysis results

\begin{tabular}{cccccccc}
\hline Independent variable & $\mathrm{R}$ & $\mathrm{R}^{2}$ & $\mathrm{~F}$ & $\mathrm{Sig} \mathrm{f}$ & $\mathrm{DF}$ & $\mathrm{T}$ & $\mathrm{Sig} \mathrm{t}$ \\
\hline & & & & & 1 & & \\
The internal control activities & 0.334 & 0.111 & 6.394 & 0.000 & 38 & 9.597 & 0.000 \\
\hline
\end{tabular}

From the previous table we see that the internal control activities have a role over the financing activities in Jordan Islamic Bank (North region), the value of $\mathrm{R}$ is (0.334), and it indicates a medium level of correlation. The $\mathrm{R}^{2}$ value for the role of internal control activities over the financing activities in Jordan Islamic Bank (North region) was (0.111), this relation is statistically acceptable because the calculated (f) value (6.394) is bigger than the (F) table value (4.00), and it has a statistical significance at $\operatorname{Sig}(\alpha \leq 0.05)$.

The $(\mathrm{T})$ test value shows the linear importance of the independent variable in the regression, the $(\mathrm{T})$ Sig. was (0.000) which is less than the Alpha value (0.05), this means that there is a linear importance for the internal control activities over the financing activities in Jordan Islamic Bank (North region). By this result, we reject the forth non-hypothesis.

H05: There is no role for the risk assessment system over the financing activities in Jordan Islamic Bank (North region).

Table 11. T-test results

\begin{tabular}{cccccc}
\hline Number & Arithmetic average & Standard deviation & T & DF & Sig (2-tailed) \\
\hline 40 & 16.79 & 6.41 & 19.07 & 39 & 0.000 \\
\hline
\end{tabular}


From the table we see that the (T) calculated value (19.07) is bigger than the (T) table value (2.021), Based on this we reject the non-hypothesis and we accept the alternative hypothesis which confirms that there is a statistically significant role at sig. $(\alpha \leq 0.05)$ for the risk assessment system over the financing activities in Jordan Islamic Bank (North region) and by comparing the arithmetic average to the comparative standard we found that this role is medium.

The researcher used the simple linear regression analysis to measure this role over the financing activities in Jordan Islamic bank (North region).

Table 12. The simple linear regression analysis results

\begin{tabular}{cccccccc}
\hline Independent variable & $\mathrm{R}$ & $\mathrm{R}^{2}$ & $\mathrm{~F}$ & Sig f & $\mathrm{DF}$ & $\mathrm{T}$ & Sig t \\
\hline $\begin{array}{c}\text { The risk assessment system adopted by the } \\
\text { internal control committees }\end{array}$ & 0.501 & 0.251 & 17.12 & 0.000 & 38 & 37.48 & 0.000 \\
\hline
\end{tabular}

From the previous table we see that the risk assessment system has a role over the financing activities in Jordan Islamic Bank (North region), the value of $\mathrm{R}$ is $(0.501)$, and it indicates a medium level of correlation. The $\mathrm{R}^{2}$ value for the effect of the risk assessment system over the financing activities in Jordan Islamic Bank (North region) was (0.251), this relation is statistically acceptable because the calculated (f) value (17.12) is bigger than the (F) table value (4.00), and it has a statistical significance at $\operatorname{Sig}(\alpha \leq 0.05)$.

The $(\mathrm{T})$ test value shows the linear importance of the independent variable in the regression, the $(\mathrm{T})$ Sig. was (0.000) which is less than the Alpha value (0.05), this means that there is a linear importance for the risk assessment system over the financing activities in Jordan Islamic Bank (North region). By this result, we reject the fifth non-hypothesis.

\section{Study Analysis Results}

1) The internal control components have a high role over the financing activities in Jordan Islamic Bank (North region).

2) There is a very high role for the internal control environment over the financing activities in Jordan Islamic Bank (North region).

3) The follow-up system has a very high role over the financing activities in Jordan Islamic Bank (North region).

4) The communication and information system has a very high role over the financing activities in Jordan Islamic Bank (North region).

5) The operational activities system has a very high role over the financing activities in Jordan Islamic Bank (North region).

6) The risk assessment system has a medium role over the financing activities in Jordan Islamic Bank (North region).

\section{Conclusions}

1) The internal control components as a whole play an important role over the financing activities in Jordan Islamic Bank (North region). This indicates the efficiency and quality of internal control inside the bank.

2) The policies and procedures that help to ensure the implementation of management views are accurate and carefully set.

3) The information and communication system has properly communicated relevant information to all parties within the Bank and within a time frame that meets the objectives of the financial reports.

4) Periodic and continuous assessment of the internal control components was accurate in examining the weaknesses of the applied control system.

5) The risk assessment system needs to be more precise in identifying the risks facing Jordan Islamic Bank (North region).

\section{Recommendations}

1) Focusing on the continuous development and increasing the efficiency of the internal control environment.

2) Maintaining the quality of policies and procedures that help to ensure the implementation of management 
views.

3) Focusing on the role of the information and communication system and developing and updating it to deliver the information appropriately to all parties within Jordan Islamic Bank (Northern Region).

4) Working on periodic and continuous assessment of the internal control components, updating them and addressing the weaknesses in them.

5) Focusing on activating the risk assessment system more in order to identify and analyze the risks facing Jordan Islamic Bank (Northern Region).

6) Continuous training for internal control staff in Jordan Islamic Bank (Northern Region).

\section{References}

Accounting and Auditing Organization for Islamic Financial Institutions. (2004). Accounting and Auditing Standards for Islamic Financial Institutions.

Al-Rawashdeh, H. A. (2017). The Role of Internal Control Components in the Maintenance of Public Funds: Applied Study on the Jordanian Ministry of Justice - North Province as Perceived by the Workers of Internal Control and Accounting Departments. International Business Research, 10(5). https://doi.org/10.5539/ibr.v10n5p189

Alvin, A. A., Randal, J. E., \& Mark, S. B. (2014). Published by Person Education 2014, p. 308.

Al-wardat, K. A. (2014). Internal Auditting Guide in Accordance with IIA International Standards (p. 313). Amman: Al-Warraq Foundation for Publishing and Distribution.

Amin, S. Z. O. (2012). Activating the Role of Internal Control System in the Electronic Commerce Environment. Journal of Kirkuk University for Administrative and Economic Sciences, 2(2), 136-163.

Edward, B., \& Edward, B. (2011). Internal Controls and the Quality of Financial Statements in Local Governments Case Study: Wakiso District. Makarere University.

Ghunaimat, A. A., \& Siyam, W. Z. (2011). Factors Affecting the Effectiveness of Internal Control Systems in the Jordanian Ministries. Jordan Journal for Business Administration, 7(4).

Hammadi, S. (2015). Evaluation of the Private Banks Experience in Algeria. Case Study of Al Baraka Bank of Algeria. Al-wadi Agency, Faculty of Economic and Commercial Sciences, Economic sciences Department.

Madhoun, R. I. (2014). Factors Influencing the Relationship Between Internal and External Auditing in Banks and their Impact on Strengthening the Internal Control System and Reducing the Cost of External Auditing (unpublished master thesis). Islamic University, Gaza, Palestine.

Rawashdeh, H. A., \& Al-Bawab, A. (2016). The Extent to Which Islamic Banks are Committed to Disclosing the Accountability of Social Responsibility in their Financial Statements (An applied study on Islamic banks operating in Jordan). Irbid National University \Accounting Department. European American Journal.

Saidin, S., \& Badara, M. (2013). Impact of the Effective Internal Control System on the Internal Audit Effectiveness at Local Government Level. Journal of Social and Development Sciences, 4(1), 16. Retrieved from http://www.jordanislamicbank.com/ar

\section{Copyrights}

Copyright for this article is retained by the author(s), with first publication rights granted to the journal.

This is an open-access article distributed under the terms and conditions of the Creative Commons Attribution license (http://creativecommons.org/licenses/by/4.0/). 